\title{
Prejudgment of the accused (Justice and Crime Coverage)
}

\section{AUTHOR}

Franziska Oehmer

\section{KEYWORDS}

judicial reporting, court reporting, representativity, media ethics

\section{BRIEF DESCRIPTION}

In some legal systems, strong prejudicial reporting can be recognized as a reason for reduced sentences in trials (e.g. in Switzerland: BGer 6B_45/2014). It is argued that the accused has already been punished by the public pillory. This variable serves to capture the extent of the implicit or explicit references to the guilt of the accused before the end of the trial (Schulz 2002).

\section{FIELD OF APPLICATION/THEORETICAL FOUNDATION} The variable "prejudgment of the accused" is of particular relevance in the context of debates on media ethics and legal philosophy. With the use of this variable, the extent to which personal rights provisions of the defendant are respected in media coverage is discussed.

\section{EXAMPLE STUDY}

Oehmer (work in progress)

\section{INFORMATION ON OEHMER (WORK IN PROGRESS)}

Author: Franziska Oehmer

Research interest: The study focuses on three sets of questions concerning 1) the selection and representativeness of court reporting, 2) the information function of court reporting and 3) the presentation of court reporting.

Object of analysis: court coverage in Swiss newspapers (Tagesanzeiger, NZZ, Neue Luzerner Zeitung, Südostschweiz, Blick, Gratiszeitung, 20Minuten)
Time frame of analysis: January 2007 - December 2017

Codebook: available (see attachment)

INFO ABOUT VARIABLE

Variable name/definition: prejudgment of the accused [Vorverurteilung des Angeklagten]

Level of analysis: Actors in most covered court case in article

Values:

1. Keine Vorverurteilung: Über den Angeklagten wird nicht wertend berichtet. Indikatoren: Mutmasslicher Täter

2. Implizite Vorverurteilung: Die Tatschuld wird implizit durch Begriffe, Wertungen oder Deutungen nahegelegt.

3. Explizite Vorverurteilung: Die Tatschuld wird als erwiesen betrachtet. Der Angeklagt wird klar als Täter identifiziert. Indikatoren: Mörder, Täter

Intercoder reliability: Holsti .88; Krippendorff's Alpha: .56 (2 Coder)

\section{REFERENCES}

Oehmer, Franziska. Die dritte Gewalt in den Medien. Eine repräsentative quantitative Inhaltsanalyse der Gerichtsberichterstattung Schweizer Medien (work in progress). [Justice in the media. A representative quantitative content analysis of court reporting in the Swiss media].

Schulz, U. (2002): Die rechtlichen Auswirkungen von Medienberichterstattung auf Strafverfahren. Frankfurt: Peter Lang. [The legal effects of media coverage on criminal proceedings]. 